\title{
Adherence level and knowledge about psychopharmacological treatment among patients discharged from psychiatric internment
}

\author{
Lucilene Cardoso ${ }^{1}$ \\ Adriana Inocenti Miasso ${ }^{1}$ \\ Sueli Aparecida Frari Galera ${ }^{2}$ \\ Beatriz Marques Maia $^{3}$ \\ Rafael Braga Esteves ${ }^{3}$
}

This exploratory, descriptive and prospective study aimed to identify the degree of adherence to psychopharmacological treatment of patients who were discharged from psychiatric hospitalization and their knowledge about their prescription and diagnosis. The study was carried out at a Mental Health Service. The sample consisted of all service clients who were discharged from psychiatric hospitalization in the data collection period. A Sociodemographic Questionnaire and the Morisky-Green Test were the instruments used. Data were analyzed through central trend measures. In total, 48 patients participated in the study. Regarding adherence, $70.8 \%$ of them showed a low adherence level to psychopharmacological treatment. Moreover, only twenty-one patients knew what their diagnosis was and most did not know or partially knew the name and dose of all prescribed medications.

Descriptors: Advance Directive Adherence; Hospitalization; Mental Health; Nursing Assessment; Psychiatric Nursing; Adhesion to the Medication.

\footnotetext{
${ }^{1}$ RN, Ph.D. in Nursing, Professor, Escola de Enfermagem de Ribeirão Preto, Universidade de São Paulo, WHO Collaborating Centre for Nursing Research Development, SP, Brazil. E-mail: Lucilene - lucilene@eerp.usp.br, Adriana - amiasso@eerp.usp.br.

${ }^{2}$ RN, Free Lecture, Associate Professor, Escola de Enfermagem de Ribeirão Preto, Universidade de São Paulo, WHO Collaborating Centre for Nursing Research Development, SP, Brazil. E-mail: sugalera@eerp.usp.br.

${ }_{3}^{3}$ Undergraduate students at the Bachelor's and Teaching Diploma Program in Nursing, Escola de Enfermagem de Ribeirão Preto, Universidade de São Paulo, WHO Collaborating Centre for Nursing Research Development, SP, Brazil. E-mail: Beatriz -bia_mmaia@hotmail.com, Rafael - rafaelbragaesteves@yahoo.com.br.
}

Corresponding Author:

Lucilene Cardoso

Universidade de São Paulo. Escola de Enfermagem de Ribeirão Preto

Departamento de Enfermagem Psiquiátrica e Ciências Humanas

Av. dos Bandeirantes, 3900

Bairro: Monte Alegre

CEP: 14040-902, Ribeirão Preto, SP, Brasil

E-mail: lucilene@eerp.usp.br 


\title{
Grau de adesão e conhecimento sobre tratamento psicofarmacológico entre pacientes egressos de internação psiquiátrica
}

O objetivo deste trabalho foi identificar o grau de adesão ao tratamento psicofarmacológico dos pacientes egressos de internação psiquiátrica e seu conhecimento quanto à sua prescrição e diagnóstico. Trata-se de estudo exploratório, descritivo, prospectivo, realizado em um núcleo de saúde mental. A amostra foi composta por todos os clientes desse serviço que tiveram alta de internação psiquiátrica, no período de coleta, sendo utilizado um questionário sociodemográfico e o teste de adesão de Morisky e Green como instrumentos. Os dados foram analisados por medidas de tendência central. Fizeram parte da amostra 48 pacientes e, em relação à adesão, observou-se que 70,8\% deles foram classificados como baixo grau de adesão ao tratamento psicofarmacológico. Além disso, apenas vinte e um pacientes sabiam informar qual era seu diagnóstico, e a maioria deles não sabia, ou sabia parcialmente, o nome e dosagem de todos os medicamentos a eles prescritos.

Descritores: Adesão a Diretivas Antecipadas; Hospitalização; Saúde Mental; Avaliação em Enfermagem; Enfermagem Psiquiátrica; Adesão à Medicação.

\section{Grado deadhesión y conocimiento sobretratamiento psicofarmacológico entre pacientes egresados de internación psiquiátrica}

\begin{abstract}
El objetivo de este trabajo fue identificar el grado de adhesión al tratamiento psicofarmacológico de los pacientes egresados de internación psiquiátrica y evaluar su conocimiento en cuanto a su prescripción y diagnóstico. Se trata de un estudio exploratorio, descriptivo, prospectivo, realizado en un Núcleo de Salud Mental. La muestra fue compuesta por todos los clientes de este servicio que tuvieron alta de internación psiquiátrica en el período de recolección siendo utilizado un Cuestionario sociodemográfico y la Prueba de Adhesión de Morisky-Green como instrumentos. Los datos fueron analizados por medidas de tendencia central. Hicieron parte de la muestra 48 pacientes; en relación a la adhesión, se observó que 70,8\% de ellos fueron clasificados con bajo grado de adhesión al tratamiento psicofarmacológico. Además de eso, apenas veintiún pacientes sabían informar cual era su diagnóstico y la mayoría de ellos no sabía o sabía parcialmente el nombre y dosis de todos los medicamentos que le fueron prescritos.
\end{abstract}

Descriptores: Adhesión a las Directivas Anticipadas; Hospitalización; Salud Mental; Evaluación en Enfermería; Enfermería Psiquiátrica; Adherencia a la Medicación.

\section{Introduction}

Patients' adherence to the prescribed medication treatment is a desirable behavior for treating all chronic conditions. The theme has received a lot of attention in different areas. In psychiatry, among other goals, adherence aims to permit psychopharmacological treatment to be of help in psychiatric symptom control, permit better disease management and minimize the risk of relapse and the need for countless consecutive psychiatric hospitalizations $^{(1)}$.

In mental disorder treatment, non-adherence to medication is observed in about $50 \%$ of people and responsible for countless harm, hampering therapeutic and psychosocial approaches, interaction between health teams and patients, besides impairing patients' social reintegration ${ }^{(2-3)}$. Recent studies involving patients diagnosed with schizophrenia suggest that the risk of relapse ranges between 3.5 and $10 \%$ per month, approximately $\mathrm{y}^{(3-4)}$ and indicate non adherence to psychopharmacological treatment as the main reason for relapse in non-hospitalized patients ${ }^{(5)}$. 
In addition, even in excellent treatment conditions, that is, supervised medication use and intense psychosocial care, the psychotic relapse rate is $20 \%$ one year after the psychotic episode. In regular conditions, that rate figures around $40 \%$, against 60 to $75 \%$ one year after the psychotic episode without treatment ${ }^{(5-6)}$.

In general, a range of factors can influence medication adherence and the lack of specialized rehabilitation programs affects patients and relatives as an often solitary challenge to find means to articulate some level of social and economic insertion, so as to try and minimize the harm caused by the disability and disadvantages deriving from this complex problem ${ }^{(7)}$.

In that sense, some studies relate the success of treatment adherence with different levels of commitment related to the patients' role, their relation with health services-professionals and with the quality of care the professional delivers. All of these involve the need for a good interpersonal relationship, knowledge, understanding and techniques that help with treatment maintenance ${ }^{(8-9)}$. Others also highlight the influence of factors regarding socio-demographic conditions, the therapeutic scheme and the nature of the illness ${ }^{(5,10)}$.

In mental health, recent studies have also inferred that patients' critical sense and/or knowledge about their disease should be preserved as protective factors for treatment maintenance and health care, indicating, on the other hand, denial of or ambivalence towards the disease and treatment as a predictive condition of treatment failure and low adherence ${ }^{(11-12)}$.

Thus, it is expected that patients with good knowledge about their disease and treatment can experience significant improvements in terms of adherence, to the extent that they gradually accept and understand their situation, resources and potentials. Although they suggest that health education can also influence patients and families' involvement in health care, few studies have addressed this issue in terms of adherence to psychiatric medication treatment.

Considering adherence to medication treatment after psychiatric internment as an important element in the prevention of relapse and part of care in community mental health services, nurses' fundamental actions are highlighted. Among other competences, they are in charge of administering, supervising and/or helping with medication use and inform their clients through health

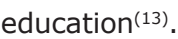

In that sense, this research was developed to identify the level of adherence to psychopharmacological treatment among patients discharged from psychiatric internment, as well as their knowledge on their diagnosis and treatment.

\section{Methods}

An exploratory, descriptive and prospective study was carried out at a Mental Health Center (NSM) affiliated with a Teaching Health Center. This public Mental Health service offers outpatient care to people as from 18 years of age and serves as a referral institution for Western Ribeirão Preto-SP, covering an estimated population of 130,688 inhabitants in the district and a population of approximately 18,006 inhabitants in the basic area.

During four months between 2007 and 2008, all patients recently discharged after psychiatric internment at a specialized service (psychiatric hospital, general hospital ward and emergency unit nursing ward) and attended at the service under analysis were monitored.

Approval for the research was obtained from the Institutional Review Board at the service. All participants signed the Informed Consent Term and received a copy.

\section{Research participants}

During four months, 54 patients discharged after internment were attended at the mental health service, representing an average 13 cases of attendance to discharged patients per month, except for those cases when the same patient was rehospitalized. All patients were invited to participate in the study, but six patients did not participate because: two refused to participate, one was transferred to another service, one patient's discharge from hospital was suspended and two did not attend the scheduled consultation, without the possibility of renewed contact due to outdated records in the network's information system. Thus, the sample comprised 48 patients who accepted and were able to participate in the study.

\section{Data collection}

Data were collected individually after nursing care to provide orientations on treatment maintenance after the medical consultation, using a questionnaire the research authors developed and Morisky and Green's adherence test $^{(14)}$. To check the questionnaire's understandability and clarity, coherence of the questions, order, the patient's understanding when listening and answering and the probable duration of the interview, first, a pilot test was accomplished with 10 patients to improve the questionnaire and compose the definitive version. Interviews were held once, at a reserved place, and data collection referred to the last 30 days of treatment.

- The questionnaire covered the following variables: Gender; Age (birth date); Patient's education; Patient's marital status; Number of children; Patient's employment 
situation; Patient's personal income; Whom the patient lives with; Housing conditions; Number of people living in the same house; Family income; Psychiatric diagnos(i)(e) s; Patient's knowledge about the disease; Manifestation time of psychiatric disorder; Opinion on the importance of psychopharmacological treatment; Knowledge on the name of prescribed drugs and prescription; Previous internments (number).

- The Morisky-Green ${ }^{(14)}$ measure of medication adherence assesses patients' behavior regarding habitual medication use through four questions with dichotomous (yes/no) answers. At least one affirmative answer to the question is considered low treatment adherence: 1- Have you ever forgotten to take your medication?; 2- Are you sometimes careless with your medication times?; 3- When you feel good, do you sometimes not take your medication?; 4When you feel bad taking the drug, do you sometimes not take it?

The collected data were stored in an Excel/2007 database and later imported to SPSS software, version 10.0 , for analysis.

\section{Data analysis}

Central trend measures were used for data analysis. The Morisky/GREEN test, comprising four questions aimed as assessing patients' behavior regarding habitual medication use, was assessed according to the following classification: high adherence level, for patients who answered all questions negatively; low adherence level, when at least one answer was affirmative ${ }^{(14)}$. In addition, it was assessed whether the low-adherence behavior was intentional or non intentional. Patients with both types of low-adherence behaviors could also be characterized ${ }^{(15)}$. For patients who gave one positive answer to any of the first two questions, the low-adherence type was classified as non intentional low adherence; in case of a positive answer to any of the last two questions, the subject was classified under intentional low adherence.

\section{Results}

\section{General characteristics of patients discharged from psychiatric internment}

The demographic, social and economic characteristics of the 48 patients in the sample are presented in Table 1 and demonstrate that 30 patients were female and 18 male, with a mean age of 39 years, ranging from 18 to 75 years. Most patients (93\%) lived with their family at the time of data collection.
Table 1 - Socio-demographic and economic characteristics of patients discharged from recente psychiatric internment

\begin{tabular}{|c|c|c|}
\hline Characteristics & $\mathbf{N}$ & $\%$ \\
\hline \multicolumn{3}{|l|}{ Gender } \\
\hline Male & 18 & 37.5 \\
\hline Female & 30 & 62.5 \\
\hline \multicolumn{3}{|l|}{ Marital status } \\
\hline Single & 19 & 39.6 \\
\hline Married/Fixed partner & 18 & 37.5 \\
\hline Divorced/Separated & 8 & 16.7 \\
\hline Widowed & 3 & 6.3 \\
\hline \multicolumn{3}{|l|}{ Children } \\
\hline None & 20 & 41.7 \\
\hline One & 8 & 16.7 \\
\hline Two & 7 & 14.6 \\
\hline Three or more & 13 & 27.0 \\
\hline \multicolumn{3}{|l|}{ Education } \\
\hline Illiterate & 2 & 4.2 \\
\hline Unfinished primary & 17 & 35.4 \\
\hline Finished primary & 7 & 14.6 \\
\hline Unfinished secondary & 9 & 18.8 \\
\hline Finished secondary & 10 & 20.8 \\
\hline Finished higher & 3 & 6.3 \\
\hline \multicolumn{3}{|l|}{ Occupation } \\
\hline Has never worked & 3 & 6.3 \\
\hline Unemployed & 12 & 25.0 \\
\hline Does occasional temporary jobs & 3 & 6.3 \\
\hline Informal regular job & 2 & 4.2 \\
\hline Registered regular job & 5 & 10.4 \\
\hline On leave & 4 & 8.3 \\
\hline Retired & 19 & 39.6 \\
\hline \multicolumn{3}{|l|}{ Personal Income (patient) ${ }^{*}$} \\
\hline None & 15 & 31.2 \\
\hline One minimum wage $(\mathrm{MW})$ & 18 & 37.5 \\
\hline Two MW & 9 & 18.8 \\
\hline Three MW & 1 & 2.1 \\
\hline Four or more MW & 5 & 10.4 \\
\hline \multicolumn{3}{|l|}{ Whom the patient lives with } \\
\hline Alone & 2 & 4.2 \\
\hline Lives with relatives & 45 & 93.8 \\
\hline Lives with friends & 1 & 2.1 \\
\hline \multicolumn{3}{|l|}{ Housing condition } \\
\hline Own & 34 & 70.8 \\
\hline Rented & 13 & 27.1 \\
\hline Other (street dweller) & 1 & 2.1 \\
\hline \multicolumn{3}{|l|}{ Number of people in the house } \\
\hline Up to two people & 12 & 25.2 \\
\hline Three or four people & 28 & 58.4 \\
\hline Five or six people & 4 & 8.2 \\
\hline Seven or eight people & 4 & 8.2 \\
\hline \multicolumn{3}{|l|}{ Family income* } \\
\hline None & 1 & 2.1 \\
\hline Two MW & 12 & 25.0 \\
\hline Three MW & 21 & 43.7 \\
\hline Four or more MW & 14 & 29.2 \\
\hline
\end{tabular}

*At the time of data collection, one minimum wage corresponded to $\mathrm{R} \$$ 380,00 .

Source: Cardoso L. Egressos de internação psiquiátrica - um olhar sobre o paciente e seu familiar cuidador [Tese de Doutorado]. Ribeirão Preto: Universidade de São Paulo, Escola de Enfermagem de Ribeirão Preto; 2008 
As for the number of children, $41.7 \%$ had none and $27.0 \%$ three or more. Patients with one or two children added up to $31.3 \%$ of the sample.

For seventeen patients, the education level was unfinished primary education (35.4\% of the sample), while two patients had never studied and three managed to finish higher education (finished higher education). It is highlighted that most patients (54.2\%) had only finished primary education or less.
Regarding professional activities, $21 \%$ of patient reporting having some kind of informal or formal job activity and $39.6 \%$ gain retirement benefits as a source of income.

Among subjects with one sole registered diagnosis, diagnoses classified under Schizophrenia and Schizotypal Disorders (33.3\%) and mood disorders (29.2\%) prevailed, as presented in Table 2.

Among all patients in the sample, 29.2\% presented more than one medical diagnosis.

Table 2 - Frequency distribution of patients discharged from recent psychiatric internment regarding diagnosis and disease time

\begin{tabular}{lcccccc}
\hline \multirow{2}{*}{ Diagnoses } & \multicolumn{3}{c}{ Time in years * } & \multicolumn{2}{c}{ Total } \\
\cline { 2 - 7 } & Less than $\mathbf{1}$ & $\mathbf{1 - 5}$ & $\mathbf{6 - 1 0}$ & $\mathbf{1 1 - 1 5}$ & $\mathbf{1 6 - 2 0}$ & N (\%) \\
\hline Schizophrenia and schizotypal disorders & 5 & 2 & 7 & 1 & 1 & $16(33.3)$ \\
Mood disorder - BAD & 3 & 1 & 1 & 0 & 1 & $6(12.5)$ \\
Depressive Mood Disorder & 5 & 1 & 1 & 0 & 1 & $8(16.7)$ \\
Somatoform pain disorder & 1 & 0 & 0 & 0 & 0 & $1(2.1)$ \\
Borderline personality & 1 & 1 & 1 & 0 & 0 & $3(6.2)$ \\
Two diagnoses (Psychiatric comorbidities) & 4 & 4 & 4 & 0 & 0 & $12(25.0)$ \\
Three diagnoses (Psychiatric comorbidities) & 1 & 1 & 0 & 0 & 0 & $2(4.2)$ \\
Total & $20(41.6)$ & $10(20.8)$ & $14(29.2)$ & $1(2.1)$ & $3(6.3)$ & $48(100.0)$ \\
\hline
\end{tabular}

$*$ median $=3.5$ years, time of disease diagnosed in full years. Figures between parentheses are percentages ( $N=48$, absolute number of interviewed patients). Source: Cardoso L. Egressos de internação psiquiátrica - um olhar sobre o paciente e seu familiar cuidador [Tese de Doutorado]. Ribeirão Preto: Universidade de São Paulo, Escola de Enfermagem de Ribeirão Preto; 2008.

Among patients discharged from psychiatric internment, it was observed that $62.5 \%$ had been hospitalized at least once before the most recent hospitalization. The number of previous hospitalizations ranged between one and thirteen. The recent hospitalization was the first psychiatric internment in their lives for $37.5 \%$ of patients in the sample. Five patients had been interned ten times before the recent internment and nine had already been hospitalized once. The mean number of internments per patient was 3.14.

The time since diagnosis was verified in full years and is described in Table 2, in comparison with the type of diagnosis. This time since diagnosis ranged between less than one year and twenty full years. The mean time since diagnosis was 4.4 years.

\section{Patients' treatment adherence and knowledge}

Regarding adherence, $70.8 \%$ were classified as low adherence to psychopharmacological treatment on the Morisky and Green test, as described in Table 3. This low adherence level was also characterized as a mixed behavior between intentional and non intentional in $40.7 \%$ of the sample.
Table 3 - Frequency distribution regarding adherence level to medication treatment and type of low adherence among patients discharged from psychiatric internment, related to the analysis based on the Morisky and Green test

\begin{tabular}{lcc}
\hline \multicolumn{1}{c}{$\begin{array}{c}\text { Adherence level and Type of low } \\
\text { adherence }\end{array}$} & Frequency & Percentage \\
\hline High adherence level & 14 & 29.2 \\
Low adherence level - intentional & 9 & 18.7 \\
Low adherence level - non intentional & 5 & 10.4 \\
Low adherence level with both types of & 20 & 40.7 \\
behavior & 48 & 100.0 \\
Total & \\
\hline
\end{tabular}

Source: Cardoso L. Egressos de internação psiquiátrica - um olhar sobre o paciente e seu familiar cuidador [Tese de Doutorado]. Ribeirão Preto: Universidade de São Paulo, Escola de Enfermagem de Ribeirão Preto; 2008.

The individual analysis of test questions is described in Table 4. On the first two test questions: have you ever forgotten to take your medication? and are you sometimes careless with your medication times?, affirmative answers predominated. On the last two, on the other hand, when you feel good, do you sometimes not take your medication? and when you feel bad taking the drug, do you sometimes not take it?, negative answers predominated. 
The largest number of patients with affirmative answers was found for question two. In other words, 28 patients (58.3\%) affirmed they had already forgotten to take their medication sometimes.

On question one, $56.3 \%$ of patients affirmed "forgetting to take their medication" and, on question two, $58.3 \%$ of patients affirmed being "careless with medication times".

Table 4 - Frequency distribution of patients discharged from psychiatric internment regarding Morisky and Green test questions

\begin{tabular}{lcc}
\hline \multirow{2}{*}{ Adherence level and Type of low adherence } & Yes & No \\
\cline { 2 - 3 } & $\mathbf{n}(\%)$ & $\mathbf{n}(\%)$ \\
\hline $\begin{array}{l}\text { 1-Have you ever forgotten to take your } \\
\text { medication? }\end{array}$ & $27(56.3)$ & $21(43.7)$ \\
$\begin{array}{l}\text { 2-Are you sometimes careless with your } \\
\text { medication times? }\end{array}$ & $28(58.3)$ & $20(41.7)$ \\
$\begin{array}{l}\text { 3-When you feel good, do you sometimes not } \\
\text { take your medication? }\end{array}$ & $23(47.9)$ & $25(52.1)$ \\
$\begin{array}{l}\text { 4-When you feel bad taking the drug, do you } \\
\text { sometimes not take it? }\end{array}$ & $19(39.6)$ & $29(60.4)$ \\
\hline
\end{tabular}

Figures between parentheses correspond to percentages of all patients $(\mathrm{N}=48)$. Source: Cardoso L. Egressos de internação psiquiátrica - um olhar sobre o paciente e seu familiar cuidador [Tese de Doutorado]. Ribeirão Preto: Universidade de São Paulo, Escola de Enfermagem de Ribeirão Preto; 2008.

Not taking one's medication due to feeling bad was the most denied test question, with $60.4 \%$ of patients saying that they did not abandon treatment even when feeling bad (Table 4). Also, $52.1 \%$ of the interviewees denied suspending medication use because they felt good.

Regarding the type of low treatment adherence these patients displayed, $40.7 \%$ of the sample was classified as low treatment adherence due to mixed behavior: intentional and non intentional. Low adherence level due to intentional behavior prevailed in nine (18.7\%) patients and low adherence level due to non intentional behavior in five (10.4\%).

Fifty-six percent of discharged patients did not know the name of the mental illness they suffered from and why they were monitored at the mental health service. Thus, only 21 patients knew the name of the mental illness they had been diagnosed with.

Regarding knowledge on the prescribed psychopharmacological treatment, most of them did not know or partially knew the name and prescription of all medication prescribed. Among these patients, 43.8\% correctly informed the names and doses of the drugs they were taking. Twenty-five percent did not know the name of any drug they were using in their treatment, as presented in Table 5.
Table 5 - Knowledge of patients discharged from recent psychiatric internment regarding the prescribed psychopharmacological treatment

\begin{tabular}{lcc}
\hline Knowledge on the prescription & Frequency & Percentage \\
\hline None & 12 & 25.0 \\
Partial & 15 & 31.2 \\
Total & 21 & 43.8 \\
Total & 48 & 100.0 \\
\hline
\end{tabular}

Source: Cardoso L. Egressos de internação psiquiátrica - um olhar sobre o paciente e seu familiar cuidador [Tese de Doutorado]. Ribeirão Preto: Universidade de São Paulo, Escola de Enfermagem de Ribeirão Preto; 2008

Although they could not inform or partially informed the name of the prescribed drugs, when asked about the importance of psychopharmacological treatment maintenance, $81.2 \%$ of patient considered medication treatment important.

\section{Discussion}

Patients' adherence to prescribed medication treatment is desirable when treating chronic conditions. In practice, it is observed that patients and their relatives present countless difficulties to maintain treatment: adverse reactions, medication interaction, inconvenient and chaotic dosage schemes; adverse effects of medication; medication cost; not understanding instructions; inadequate health education for patients; health service deficiency; deficient physician-patient relation, among others ${ }^{(16)}$.

In that sense, this research among discharged patients permitted the identification of important aspects regarding adherence to psychopharmacological treatment, such as the prevalence of severe and persistent mental disorder diagnoses, patients' low knowledge levels regarding their prescription and the time since diagnosis.

Like in different studies on medication treatment adherence among chronic patients, most patients discharged from psychiatric internment present low treatment adherence levels, to psychopharmacological treatment in this case ${ }^{(17)}$. This results demonstrates a severe situation during the extra-hospital treatment maintenance period, which is critical for patients and families, which needs more attentive supervision by mental health professionals.

Regarding the type of patients' low adherence, it was observed that mixed behavior predominated, ranging between intentional and non intentional. In other words, patients sometimes forget to take their medication, are careless with medication times and also do not take their medication when they feel well or when the medication makes them feel bad. 
Although this type of behavior seems to be a controversial result, it is important to observe that, in psychiatric illnesses, characterized by chronicity, constant symptom manifestations impair patients' critical sense, which can explain their unpredictable posture in terms of low treatment adherence.

In addition, their low knowledge levels on their prescription reinforce the idea that low adherence behavior may be related with other factors, such as "not considering themselves ill", which generates dissatisfaction with medication use because they "feel well", bringing about intentional low adherence. Studies demonstrate that the fact that these patients feel good or bad, due to medication use, influences their decision making regarding treatment adherence ${ }^{(12)}$.

As for the diagnoses, the higher prevalence of patients classified under Schizophrenia, schizotypal disorders, delusional disorders and in the group of Mood Disorders (F20-F29; F31 to F33, ICD-10) was evidenced, data remitting to similar samples in various psychiatric

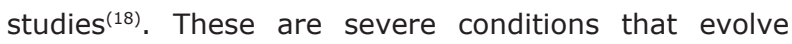
towards chronicity, often accompanied by symptoms that limit patients' labor, social and leisure activities and also trigger discrimination and stigmatization ${ }^{(19-20)}$.

In view of that aspect, the low education and socioeconomic levels that were evidenced may be related with the severity of the symptoms manifested in these conditions. The constant manifestation of psychiatric symptoms, constant relapses and rehospitalizations and adverse effects of medication treatment often hamper mental patients' relations with their family and social context, impairing their performance of daily activities $^{(20)}$.

This severity of mental illnesses may be related with low treatment adherence and knowledge deficit regarding the mean prescription most discharged patients presented, who were unable to inform precisely the name of the medication they used and/or the dose. Studies indicate that the severity of the psychiatric disorder, manifested through significant cognitive losses, such as memorization difficulty, can constitute a factor for various daily limitations, including in treatment adherence $^{(12)}$.

In view of this knowledge deficit, studies indicate that interventions like behavioral cognitive therapy, family therapies and psycho-education can collaborate towards successful treatment adherence, significantly reducing relapse and rehospitalization(11,21). Therefore, considering patients and families' knowledge and beliefs on maintaining the prescribed psychiatric treatment can help health professionals to provide better orientations and health care to these clients. This arouses reflections as to what data have supported care planning for patients discharged from internment in community services?

The need for better care planning gains even further relevance when considering the context and moment in these discharged patients' lives as, in the present study, $41 \%$ of patients had lived with the mental illness for less than one year. This period is marked by great conflicts to understand and accept the illness, in view of lack of knowledge, prejudice and stigmas surrounding mental disorders, often marked by behavioral alterations, mood swings, social isolation, emotional and cognitive losses, family conflicts, attention and concentration difficulties $^{(22)}$.

Studies describe the first years of the disease as a period when patients and relatives experience great needs for attention and orientation on the mental illness and its treatment ${ }^{(6,23)}$. Besides, no programs are offered in the country yet which act early in view of mental disorder diagnoses, evidencing that these clients often are predestined to lack of care.

The results evidence the importance of nursing actions closer to patients, with care systemization as a resource to survey these clients' needs. The development of protocols to identify signs of relapse can collaborate with psychiatric treatment maintenance.

\section{Conclusion}

The low adherence level most patients in this study manifested reinforces the importance of the theme and the need for a professional approach to this behavior, with a view to improving the care offered in mental health services. Adherence is an important aspect for treatment maintenance of mental patients outside the internment regime.

The limited number of subjects in this sample and the use of one single service as a reference were considered limiting factors that made further analyses and inferences on the theme impossible. Based on this study, the researchers intend to improve the data collection instruments used and to develop a longterm study based on systemized nursing intervention involving this clientele.

Thus, nursing activities should consider care systemization and be able to contribute to the prevention of relapse, minimize the need for rehospitalizations and improve patients' relations with their social context. More humanized attendance, with the support of adequate 
technologies, can contribute to the development of better care delivery and to the establishment of trust between professional, patient and family.

Therefore, knowing patients discharged from psychiatric internment today permits identifying characteristics that can support the determination of the best treatment and professional support to patients and their caregivers. The discharged patients analyzed in this research represent the population attended at a public health service and presented important aspects to be taken into account in psychiatric treatment maintenance.

\section{References}

1. Bechelli LPC. Long-acting antipsychotics in the maintenance treatment of schizophrenia: Part I. Foundations of its development, benefits and acceptance level in different countries and cultures. Rev. Latino-Am. Enfermagem. 2003;11(3):341-9.

2. Cardoso L, Galera, SAF. Perfil demográfico e clínico de pessoas que fazem uso de Decanoato de Haloperidol. [Dissertação mestrado]. Ribeirão Preto: Escola de Enfermagem de Ribeirão Preto/USP; 2006. 78 p.

3. Csernansky JG, Schuchart EK. [A recaída e a rehospitalização avaliadas nos pacientes com esquizofrenia: efeitos de antipsicóticos de segunda geração]. CNS Drugs. 2002;16(7):473-84.

4. Davis JM, Chen N. [Escolha da medicamentação de manutenção para a esquizofrenia]. J Clin Psychiatry. 2003;64 Suppl 16:24-33.

5. Yamada K, Watanabe K, Nemoto N, Fujita H, Chikaraishi

C, Yamauchi $K$, et al. [Predisposição a não adesão à medicamentação nos pacientes não hospitalizados com a esquizofrenia: uma continuação de 2 anos]. Psychiatry Res. 2006 Jan 30;141(1):61-9. Epub 2005 Nov 28.

6. Van Meijel B, Gaga MV, Kahn RS, Grypdonck M. [A prática do reconhecimento e da intervenção breve para impedir a recaída psicótica nos pacientes com esquizofrenia: uma parte exploratória 2 do estudo]. J Psychiatr Mental Health Nurs. 2002; 9:357-63.

7. Villares CC, Natel MT, Ribeiro IB. Conversando com familiares sobre a esquizofrenia. Psychiatry on Line [periódico na internet] 1999; 4(4). [acesso em: 23 abril 2010]. Disponível em: http://www.polbr.med.br/ arquivo/esq0599.htm

8. Colombrini MRC, Lopes MHBM, Figueiredo RM. Adesão à terapia antiretroviral para HIV/AIDS. Rev EsC Enferm USP. 2006;40(4):576-81.
9. Guaragna BFP, Ludwig MLM, Cruz ALP, Graciotto A, Schatkoski AM. Implantação do programa de adesão ao tratamento de HIV/aids: Relato de experiência. Rev HCPA 2007;27(2):35-8.

10. Vermeire E; Hearnshaw H; Van Royen P; Denekens

J. [Adesão do paciente ao tratamento: três décadas da pesquisa. Uma revisão detalhada]. J Clin Pharm Ther. $2001 ; 26: 331-45$.

11. Santin A, Ceresér K, Rosa A. Adesão ao tratamento no transtorno bipolar. Rev Psiq Clín. 2005;32(Supl 1):105-9.

12. Miasso AI, Cassiani SHB, Pedrão LJ. Bipolar affective disorder and medication therapy: identifying barriers. Rev. Latino-Am. Enfermagem. 2008 Ago;16(4):739-45. 13. Lei n. 7498 de 25 de julho de 1986 (BR). Dispõe sobre a regulamentação do exercício da enfermagem e dá outras providências. DOU. 1986 jul. 26:seção 1; 9273-5.

14. Morisky DE, Green LW, Levine DM. Concurrent and predictive validity of self-reported measure of medication adherence. Med Care. 1986;24:67-74.

15. Sewitch MJ, Abrahamowicz M, Burkun A, Bitton A, Wild GE, Cohen A, et al. Dobkin PL. Patient nonadherence to medication in inflammatory Bowel disease. Am J Gastroenterol. 2003; 98(7):1535-44.

16. Castro MS, Fuchs FD. Abordagens para aumentar a adesão ao tratamento em pacientes com hipertensão arterial de difícil controle. Rev Bras Hipertens. 2008;15(1):25-7.

17. Strelec MAAM, Pierin AMG, Mion JD. A influência dos conhecimentos sobre a doença e a atitude frente à tomada dos remédios no controle da hipertensão. Arq Bras Cardiol. 2003; 81(4):343-8.

18. Gomes MPC, Couto MCV, Pepe VLE, Almeida LM, Delgado PGG, Coutinho ESF. Censo de pacientes internados em uma instituição asilar no estado do Rio de Janeiro: dados preliminares. Cad Saúde Pública. 2002;18:1803-7.

19. Organizações Mundiais de Saúde, 2001. Relatório sobre a Saúde no Mundo - Saúde Mental: Nova Concepção, Nova Esperança. Geneva; 2001.

20. Carvalho RJL. Utilização de recursos e custos diretos da esquizofrenia para o setor público do estado de São Paulo [dissertação de mestrado]. São Paulo: Escola Paulista de Medicina/UNIFESP; 2000.

21. Colom F, Vieta E, Sanchez-Moreno J, MartínezArán A, Torrent $C$, Reinares $M$, et al. Psychoeducation in Bipolar Patients with Comorbid Personality Disorders. Bipolar Disord. 2004;6(4):294-8. 
22. Woods SW, Stolar M, Sernyak MJ, Charney DS [Consistência da superioridade de antipsicóticos atípicos ao placebo em ensaios clínicos recentes]. Biol Psychiatry. 2001;49(1): 64-70.

23. Newstead L, Kelly M. [Intervenção precoce na psicose: quem ganha, quem perde, quem paga o preço?] J Psychiatr Mental Health Nurs. 2003; 10:83-8. 